\title{
Does exchange rate affect the foreign tourist arrivals? Evidence in an emerging tourist market
}

\author{
Le Thanh Tung ${ }^{a^{*}}$
}

${ }^{a}$ Faculty of Economics and Public Management, Ho Chi Minh City Open University, Vietnam

\begin{tabular}{l}
\hline C H R O N I C L E \\
\hline Article history: \\
Received: December 05, 2018 \\
Received in revised format: April \\
192019 \\
Accepted: April 29, 2019 \\
Available online: \\
April 30, 2019 \\
\hline Keywords: \\
Exchange rate \\
Monetary policy \\
Tourism sector \\
Tourism service \\
Tourism demand \\
Foreign visitor \\
Emerging market \\
Vietnam \\
\hline
\end{tabular}

\section{A B S T R A C T}

\begin{abstract}
The rate of foreign tourist arrivals coming to Vietnam as an emerging tourism market has been increased significantly bringing enormous benefits for improving the socio-economic indicators. The purpose of this paper is to examine the impact of exchange rate policy on the number of foreign tourist arrivals in Vietnam over the period 2006-2018. Our regression results show the exchange rate maintained a positive impact on the demand of foreign tourists and indicate that the domestic currency devaluation also had a positive effect on the number of foreign tourists to Vietnam. Besides, the quantitative result also indicates the number of foreign tourist arrival in the early periods had a positive impact on itself in the current period. Furthermore, the Granger causality test confirms the existence of a one-way causal relationship between the exchange rate and the number of foreign tourist arrivals. Finally, the paper provides some implications for policymakers in order to efficiently use the exchange rate policy to increase the number of foreign tourist arrivals in the coming time.
\end{abstract}

C 2019 by the authors; licensee Growing Science, Canad

\section{Introduction}

The exchange rate policy is one the most important factors in the macroeconomic policies to help connect an economy with the global market. For operating the open economy model in the context of increasing globalization, the government must consider more and more about the real effects of her exchange rate policy on the domestic economy. There are many economic theories that sketch out how exchange rate movements affect a national trading relationship with other economies. The popular effect is that highervalued currency makes a country's imports less expensive and its exports more expensive in foreign markets. Otherwise, a lower-valued currency makes a country's imports more expensive and its exports less expensive in foreign markets. A higher exchange rate can be expected to worsen a country's balance of trade, while a lower exchange rate can be forecasted to improve it. However, the fluctuation in the exchange rate affects not only the trade balance for goods but also the prices of services across countries. Besides, the adding of the exchange rate on the tourism demand equation is fairly persuasiveness. When a country's currency devalues, international tourism becomes less expensive and, consequently, should result in increased foreign tourists to that country (Vita \& Kyaw, 2013). There have been some studies showing the impact of the exchange rate on the national trade balance, but there are only a few studies aimed at exploring the impact of exchange rate policy on service sector such as tourism, unfortunately, * Corresponding author.

E-mail address: tung.lt@ou.edu.vn (L. T. Tung) 
most of the evidences coming from the developed economies (Balaguer \& Cantavella-Jordá, 2002; Quadri \& Zheng, 2010; Surugui et al., 2011; Yazdi \& Khanalizadeh, 2017). In macro-economic terms, spending by international visitors counts as exports for the destination country and as imports for the country of residence of the visitors (World Tourism Organization, 2017).

In recent decades, tourism has been regarded as a key economic sector in most developed and developing countries. The statistics from the World Economic Forum also emphasizes that the tourism industry and its enabling ecosystem was recognized with great and significant contributions to economic growth when accounting by $10 \%$ of Global Gross domestic product (World Economic Forum, 2017). Besides, the expenditure of international visitors reached $\$ 1.200$ billion and created nearly $10 \%$ of global employment (292 million jobs) in the year 2016 (World Tourism Organization, 2017). The report of the World Tourism Organization also calculated that the international arrivals would reach 1.4 billion by 2020 and 1.8 billion people by the year 2030. Thus the tourist sector has the potential to play an important role in creating quality employment opportunities as well as a force to restore the biodiversity in worldwide and help built the strong bridges to join the people living and the cultures (World Tourism Organization, 2017). Vietnam has been expected as "a new economic tiger" in Asia and listed in the group of the fastest growing economies worldwide over the past three decades. In detail, this economy has reached an annual average growth rate of $6.6 \%$ per year for the previous 20 years (World Bank, 2018). Based on an economic booming, this is not surprising that the Vietnamese tourism destinations are developing as never before. Not only in fast economic growth, but Vietnam also has a convenient geographic for developing the tourism sector when it locates in the center of Southeast Asia and between a busy transportation way from the East to West. So Vietnam has been considered as one of the emerging tourist markets in the Asia-Pacific region in recent years (World Economic Forum, 2017). In fact, besides the fast economic growth, Vietnam has many strengths in the way to develop the tourism industry based on its long history of development over many dynasties for 4000 years. Vietnam also has a large population size of about 93 million people (in 2017) and includes 54 ethnic communities with many diverse cultural heritages throughout the territory. A strong point in Vietnam's tourism development is that this country has a long coastline running along its territory for nearly $3300 \mathrm{~km}$ with many beautiful natural bays, romantic islands, as well as the tropical continental shelf, stretches across the East Sea. Besides, Vietnamese cuisine has many foods considered at the top of the tourism field (Clark \& Miller, 2017).

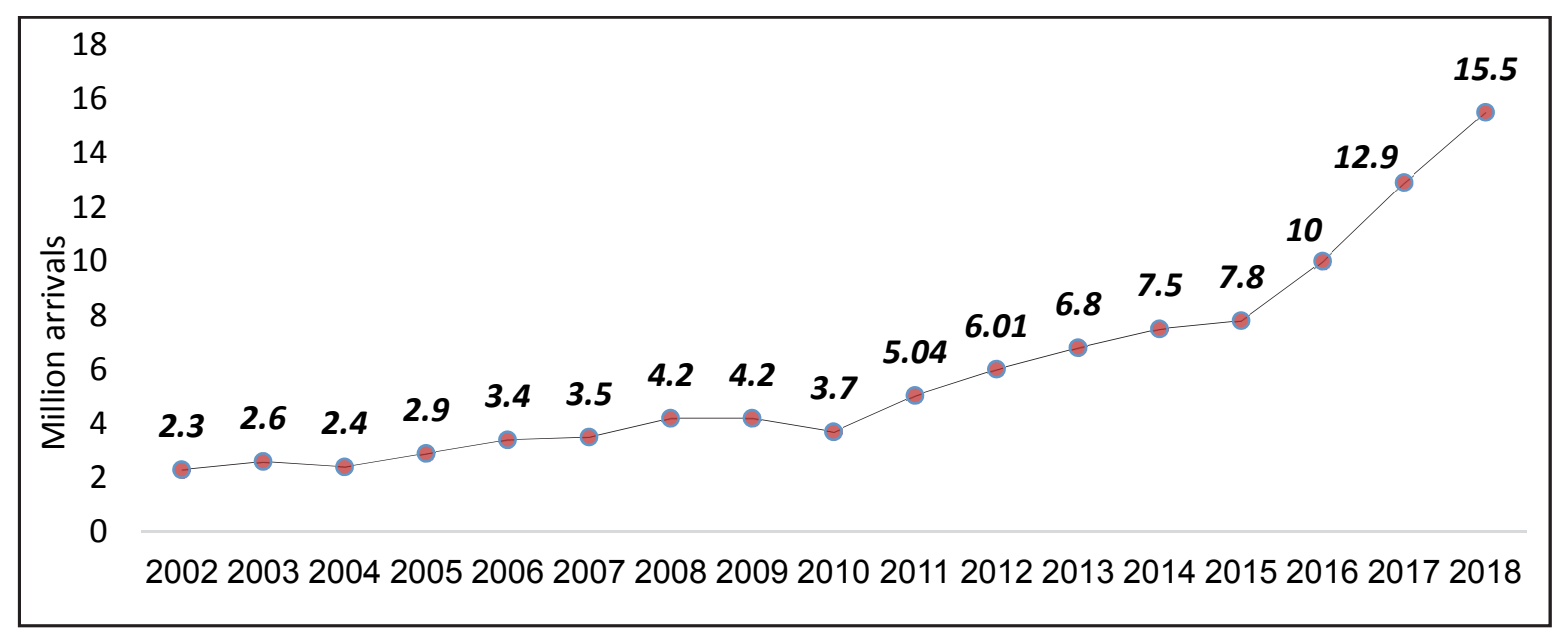

Fig. 1. The annual number of foreign tourist arrivals to Vietnam over 2002-2018

Therefore, the Vietnamese tourism industry has made great leaps and bounds in recent years and it has been gradually becoming a key sector among the leading services in this economy. The statistics of the Vietnam National Administration of Tourism show a significant increase in the number of foreign tourists over the previous decades and especially tend to increase sharply from 2011 onwards. For the period 2002-2018, the foreign tourist arrival to Vietnam has risen at an impressive rate as $12.2 \%$ per year with many huge social benefits, and the Vietnamese tourism sector also is exhibiting the fastest growth rate 
in Southeast Asia region. In detail, the number of foreign visitors has reached a record of 12.9 million in 2017 and twice as much as in 2011 and 5.6 times compared with 2002 (see Fig. 1). Vietnam's tourism management agencies also estimate that the number of foreign tourists may reach a new record of 15.5 million (a rising rate as 20\%) by the end of 2018 (Vietnam National Administration of Tourism, 2018).

On the other hand, the statistics from the Vietnam National Administration of Tourism confirmed that there had been a strongly increase in the tourism revenue. The revenue was risen significantly for the period 2010-2017, from VND 96 trillion (as USD 4.3 billion) in 2010 to VND 510 trillion (as USD 23 billion) in 2017. Besides, the revenue average growth was computed at $26.9 \%$ per year for this period. In 2017, the tourism sector contributed over $7 \%$ of the Gross domestic product (GDP) and made employment for nearly 4.8 million people in Vietnam (Vietnam National Administration of Tourism, 2018). The tourism also helps to link the urban to rural regions, from coastal areas, islands to mountainous areas in many economic activities around the country. Tourism development contributes positively to reduce the unemployment rate and poverty rate as well as narrow the gap of the income inequality among the regions in Vietnam. In 2018, the Vietnam National Administration of Tourism forecasts the revenue of this sector can be reached at VND 620 trillion (as USD 28 billion) with an increased rate as $21.4 \%$ compared with the previous year. Continuing the success trend, the Vietnamese policymakers make a target to reach 18 million foreign tourist arrivals and the revenue would still grow at double digits in the year 2019. According to the rankings of the World Economic Forum in the period 2007-2017, there were improving steps of Vietnam in the world tourism map. In detail, the tourism of Vietnam had increased 20 steps in the international ranking for ten years (see Fig. 2). In 2017, the report of the World Tourist Organization pointed that Vietnam was the leading one in the tourism growth rate in Southeast Asia region with the growth was 26\% compared with Thailand at $8.9 \%$ and Singapore at $7.1 \%$ and the Vietnamese tourism sector was ranked $67^{\text {th }}$ among 136 economies worldwide, with a raising by eight places compared the previous year (World Economic Forum, 2017). Furthermore, the World Economic Forum's ranking in 2017 show that Vietnam sharply flourished in recent years and maintained the fourth level in the 15 most improved countries in the tourist competitiveness index (World Economic Forum, 2017). In 2018, The World Tourism Organization continuously ranked the Vietnamese tourism growth rate at the seventh in the global as well as was the unique destination in Southeast Asia region successfully staying in the top ten markets.

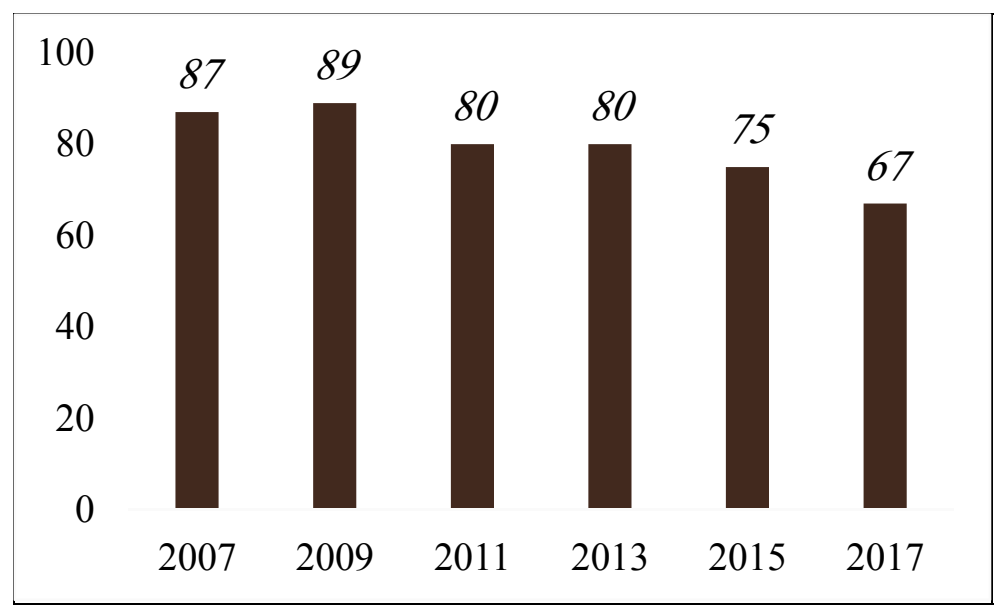

Note: The lower order is the better in the rankings

Fig. 2. The ranking level of Vietnam's tourism sector in 2007-2017

Looking back at the Vietnamese government policies that can relate directly to the demand of foreign visitors, the exchange rate policy always is considered as the most effective variable in the macro indicators during this period (Webber, 2001). However, the exchange rate and tourist demand nexus still do not provide sufficient evidence for the case of Vietnam. The statistics from the State Bank of Vietnam confirm that the nominal exchange rate between Vietnam dong (VND) and US dollar (USD) was increased by $2.43 \%$ per year on average during the period 2002-2017 (meaning that the VND has been 
devalued accordingly). However, in the period 2010-2017, the devaluation rate of VND against USD was higher $(2.84 \%$ ) compared with the $2002-2009$ period which had a rate of $2 \%$ per year. As the economic theories indicate, the fluctuation of exchange rates often has a lag time to have an effect on the macro indicators of economies. As we can see from Fig. 1, since 2011, the number of foreign tourists entering Viet Nam was increased but that incident never happened in previous years. Specifically, in 2010 , the number of foreign tourists increased only about 1.6 times of year 2002, however, the growth of 2018 is very far compared to 2010 with about 4.05 times. The statistics have shown explosive growth in the number of foreign tourists coming to Vietnam for the years. So, there is a research question: "Is the devaluation of VND stronger since 2010 related to the explosion of foreign tourists entering Vietnam?". This is an interesting issue which brings important policy implications regarding the administration of the exchange rate regime in tourism emerging countries. According to the international economic theories, when the exchange rate between the domestic currency and the foreign currency rises (the host country devalues the domestic currency), then the domestic price of goods and services decreases in a similar way compared with the price of foreign goods and services. An important question should have a clear answer, besides the factors related to location, culture or natural beauty are other factors coming from the exchange rate policy. Is the exchange rate policy related to whether tourists are growing rapidly or not? Has the exchange rate policy of the Vietnamese government increased the number of foreign tourists? This is an intriguing question because the evidence is good reference experiences for other countries since Vietnam is a rising star in the tourism economy in the world. Besides, the research results in Vietnam are also a useful reference for policymakers in other countries in an effort to improve the position of the tourism industry in the economy of their own countries.

The structure of our paper has 5 sections. Section 2 presents the literature review. The research methodologies, econometric models and source of data are shown in Section 3. In Section 4, we have quantitative results and discussions. Finally, Section 5 presents conclusions and some policy implications.

\section{Literature review}

The tourism industry is gradually being considered as the key economic sector in many countries and the globalization process is also spreading the role of tourism over the world (World Tourism Organization, 2017). Therefore, there are many studies focusing on tourism with many different aspects of the macro indicators. The relationship between the exchange rate and the demand for foreign tourists has also been studied in some countries, however, most of these studies have been accomplished in developed countries. In a study in Spain, Balaguer and Cantavella-Jordá (2002) examined the role of tourism for the long-run economic development of the economy. The study result concluded that the tourism-led growth hypothesis was confirmed by the cointegration and causality testing. The results also indicated there was a two-way causality relationship between the real effective exchange rate and international tourist demand in the case of Spain. The evidence implied that the policymaker could use the exchange policy as a tool for increasing the international tourist earning in order to support economic growth. In another European country, Quadri and Zheng (2010) analyzed the relationship between exchange rates and international arrivals of 19 host countries in the case of Italy. However, the impacts had some differences between countries. The impacts only had the statistical significance in 8 countries, the results found exchange rates resulted in no significance with international tourist arrivals in eleven of the nineteen nation pairs examined. The findings could help the policymakers further understand the impact of exchange rates on Italian tourism. Continuously, Surugui et al. (2011) analyzed the determinants of international tourism demand for Romania. The data was collected from the international tourist arrivals from 23 European countries in the period 1997-2008. The result showed that the relative price variable was one in the macro indicators could determinant of tourism flows to Romania. The authors also concluded that the relative price (depended on the exchange rate) had a negative impact on the international tourism demand in the case of Romania in the study period. Tang et al. (2016) investigated the relationship between tourism demand and exchange rate in China. The data was collected from the international tourist 
arrivals of 6 countries in the period of 1994-2011. However, the quantitative result found that the volatility of the exchange rate was not a determinant factor in fluctuation of the tourism demand from the countries being studied in this study.

In an investigated study in the US's economy, Yazdi and Khanalizadeh (2017) analyzed the determinants of international tourism demand for the period 1995-2014. The authors used a panel dataset of tourist arrivals among 14 countries with the gravity framework. The result presented that the real gross domestic product, consumer price index, real exchange rate, as well as certain specific events, have significant impacts on international tourism demand. In detail, the real exchange rate has a negative relation to tourist arrivals in the USA in the study period. In the Asia-Pacific region, Lim and Zhu (2017) studied the tourism demand for Singapore. The author used the real exchange rate in a group of variables as determinants of tourism demand growth. The results represented that the real exchange rate (as a price variable) elasticity was negatively significant, with an elasticities range of -0.275 and -0.34 . The authors concluded that the tourism demand by the Asian markets was less income-sensitive than that of the nonAsian counterparts in the long term. In the case of emerging tourist markets, despite these countries has had fast tourism growth for previous years, however, there are few studies which focus on the tourism sector in these economies. Besides, there is almost no evidence focusing on the relationship between exchange rates and the number of foreign tourists to emerging tourist markets. McDowall and Wang (2009) performed an analysis of international tourism development in Thailand over the period of 19942007. However, the exchange rate was listed the strengths table by the SWOT method. The study implied that the exchange rate may have a negative impact on international tourism development (as well as foreign tourist arrivals) in Thailand. In another result which can make policymakers more worry about the exchange rate regime, Meo et al. (2018) found a negative and significant effect of the exchange rate on the long-term tourism demand in Pakistan. Not only in Vietnam, but the exchange rate theme also has not been studied much in other emerging tourism economies. Thus there is a clearly experimental research gap on the impact of exchange rate policy on tourism demand through the fluctuation of the number of foreign tourists. Therefore, our research results are expected to bring some useful new findings to policymakers as well as businesses in this field in tourist emerging economies in the world.

\section{Methodology and data}

For doing the study targets, our research strategy will include two main steps. In the first step, the Ordinary Least Squares (OLS) estimation will be used to analyze the impact of the exchange rate on the number of foreign tourists in Vietnam. In the second step, we apply the Granger causality test (Granger, 1988) to deep analysis this relationship thought the causal relationship between the exchange rate and the foreign tourist arrivals entering Vietnam in the research period. First, to explore the impact of exchange rates on tourism demand for foreign visitors to Vietnam, our research model is represented as the following form:

$$
\mathrm{LFTA}_{\mathrm{t}}=\beta_{0}+\alpha_{1} \mathrm{LEXCH}_{\mathrm{t}}+\alpha_{2} \mathrm{WTO}_{\mathrm{t}}+\beta_{1} \mathrm{LFTA}_{\mathrm{t}-1}+\beta_{2} \mathrm{LFTA}_{\mathrm{t}-2}+\ldots+\varphi_{\mathrm{n}} \mathrm{LFTA}_{\mathrm{t}-\mathrm{n}}+\varepsilon_{\mathrm{t}},
$$

where: LFTA is the natural logarithm of the foreign tourist arrivals, the lag variables of LFTA are included in the econometric model to analyze the spreading impact of the previous visitors to the current number of visitors. The WTO variable is a dummy variable to explore the impact of Vietnam's accession to the World Trade Organization (WTO) on the number of foreign tourists coming to this country. The WTO variable is seen as a proxy for international integration variable in the econometric model. Because Vietnam has joined as a member of the World Trade Organization since November 2007, the WTO variable is defined as follows:

$$
W T O=\left\{\begin{array}{lc}
0 & \text { Month }<\text { November, } 2007 \\
1 & \text { Month } \geq \text { November, } 2007
\end{array}\right.
$$

The estimation of the Eq. (1) is accomplished by the Ordinary Least Squares method with some different lags of the number of foreign tourist arrivals to Vietnam. Besides, diagnostic tests for the reliability of regression results including the serial correlation test (LM test) as well as the heteroskedasticity test 
(White test) used simultaneously to conclude the standard of estimated results. Based on the statistics of these variables in the case of Vietnam over the study period, we expect a positive relationship between the exchange rate and the number of foreign tourists coming to Vietnam during previous years. In the next step, we will test the causal relationship between the exchange rate and the foreign tourist arrivals to Vietnam by applying the Granger causality method (1988). The Granger causality test is expressed as follows. If a time series $X$ is defined as Granger causality to the time series $\mathrm{Y}$, this conclusion is made through a test sequence t-tests as well as F-tests on the lagged values of $\mathrm{X}$ (the same will be done with the lagged values of $Y$ ). The Granger causal is confirmed when X's values provide statistically significant information about forecasting values of Y's values. According to Gujarati (2004), we can do a Granger causality test based on the using of a Vector Autoregression (VAR) model. The testing equation is represented as the following forms:

$$
\begin{aligned}
& \text { LFTA }_{t}=\beta_{0}+\beta_{1} \text { LFTA }_{t-1}+\ldots+\beta_{\mathrm{k}} \text { LFRTA }_{\mathrm{t}-\mathrm{k}}+\varphi_{1} \mathrm{LEXCH}_{\mathrm{t}-1}+\ldots+\varphi_{\mathrm{k}} \mathrm{LEXCH}_{\mathrm{t}-\mathrm{k}}+\varepsilon_{\mathrm{t}} \\
& \mathrm{LEXCH}_{\mathrm{t}}=\beta_{0}+\beta_{1} \mathrm{LEXCH}_{\mathrm{t}-1}+\ldots+\beta_{\mathrm{k}} \mathrm{LEXCH}_{\mathrm{t}-\mathrm{k}}+\varphi_{1} \mathrm{LFTA}_{\mathrm{t}-1}+\ldots+\varphi_{\mathrm{k}} \mathrm{LFTA}_{\mathrm{t}-\mathrm{k}}+\delta_{\mathrm{t}}
\end{aligned}
$$

After this step, we will test the null hypothesis for the equations:

$$
\varphi_{1}=\varphi_{2}=\varphi_{3}=\ldots=\varphi_{\mathrm{k}}=0
$$

The null hypothesis of the exchange rate $(\mathrm{LEXCH})$ does not Granger causality on the number of foreign visitors (LFTA) is tested in Eq. (3) and the null hypothesis of the number of foreign visitors (LFTA) does not Granger causality on the exchange rate $(\mathrm{LEXCH})$ is tested in Eq. (4). In order to identify the impact of exchange rate on foreign tourist arrivals, our article uses monthly data of foreign tourist arrivals coming to Vietnam. The number of foreign tourists is sourced from the Vietnam National Administration of Tourism from January 2006 to June 2018. The research data includes 150 observations. Unit of the number of foreign tourists includes a thousand people. The exchange rate used is the nominal exchange rate between VND and USD and collected from the State Bank of Vietnam. Before conducting quantitative analysis by OLS regression method as well as the Granger causality test, our data are converted to the natural logarithm forms. The descriptive statistics and the graphs of variables are shown below.

Table 1

The descriptive statistics for variables

\begin{tabular}{cccccrrrrr}
\hline Variable & Mean & Median & \multicolumn{1}{c}{ Max } & \multicolumn{1}{c}{ Min } & \multicolumn{1}{c}{ Skewness } & Kurtosis & Jarque Bera & Prob. & Obs. \\
\hline LFTA & 2.722 & 2.723 & 3.155 & 2.322 & 0.270 & 2.259 & 5.262 & 0.072 & 150 \\
LEXCH & 4.287 & 4.320 & 4.350 & 4.200 & -0.481 & 1.548 & 18.96 & 0.000 & 150 \\
\hline
\end{tabular}

LFTA
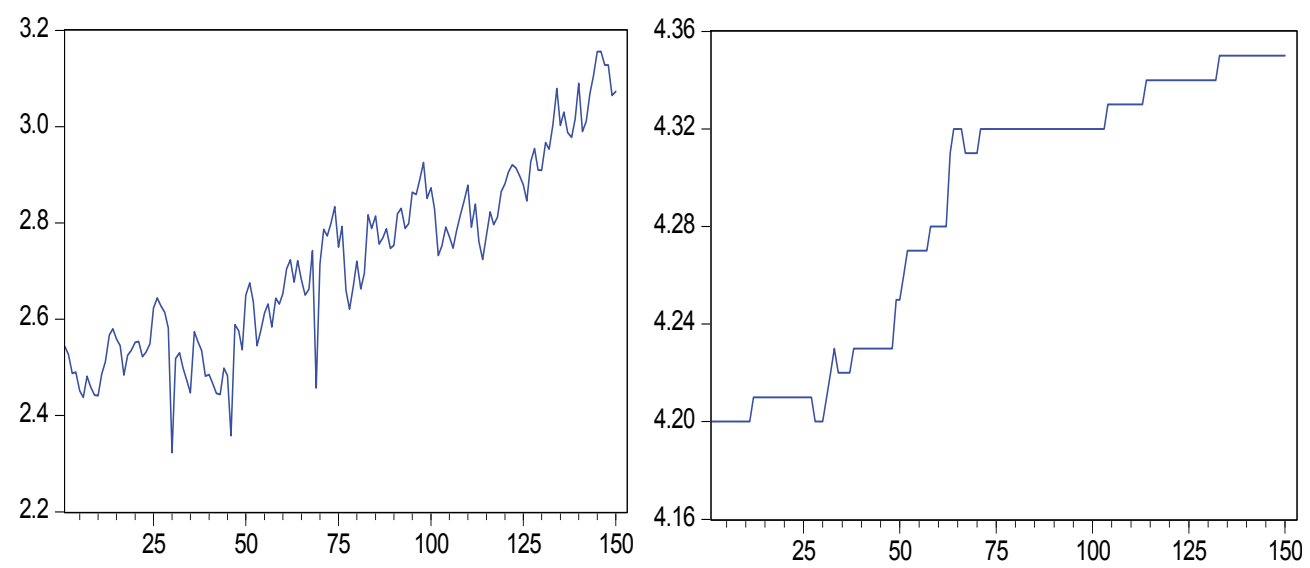

Fig. 3. The natural Logarit of international tourist arrivals and exchange rate 


\section{Result and Discussion}

Following our estimated strategy in the previous section, in the first step, to explore the impact of exchange rate policy on the foreign tourist arrivals to Vietnam, the Eq. (1) will be estimated with different lags of the LFTA variable. After that, the estimated results are continuously checked by some diagnostic tests because in many cases of statistical analysis we are not sure if our regression results are correctly specified. The diagnostic tests will be done to confirm that the estimation results are free of the serial correlation as well as the heteroskedasticity phenomenon.

To identify the optimal lag length of the LFTA variable, the estimated results are compared on some information such as the Adjusted R-squared values, diagnostic testing results and the fitness of estimated coefficients compared the reality. In particular, the Adjusted R-squared can penalize the model for adding more useless variables, because the Adjusted R-squared decreases when we add useless variables to our model, and increases when we add significant variables (Gurajati, 2004).

In this part, we will use the OLS method to estimate Eq. (1) with different lags of the LFTA variable. Due to the limitation of the number of degrees of freedom, we limit the number of equations to be estimated at 8 versions. The regression results are summarized in the table below.

Table 2

The estimated results

\begin{tabular}{|c|c|c|c|c|}
\hline \multicolumn{5}{|c|}{ Dependent Variable: LFTA } \\
\hline \multirow[t]{2}{*}{ Variables } & Model 1 & Model 2 & Model 3 & Model 4 \\
\hline & \multicolumn{4}{|c|}{ Coefficient } \\
\hline \multirow[t]{2}{*}{ Constant } & $-10.00590 * * *$ & $-12.17750 * * *$ & $-3.159445 * * *$ & $-2.653040 * * *$ \\
\hline & {$[-16.36911]$} & {$[-15.46420]$} & {$[-3.829704]$} & {$[-3.170543]$} \\
\hline \multirow[t]{2}{*}{ LEXCH } & $2.964363 * * *$ & $3.492972 * * *$ & $0.899258 * * *$ & $0.751489 * * *$ \\
\hline & {$[20.82394]$} & {$[18.65808]$} & {$[4.050121]$} & [3.320698] \\
\hline \multirow[t]{2}{*}{ WTO } & & $-0.116735 * * *$ & -0.029062 & -0.024316 \\
\hline & & {$[-4.087202]$} & {$[-1.463759]$} & {$[-1.228664]$} \\
\hline \multirow[t]{2}{*}{ LFTA(-1) } & & & $0.752150 * * *$ & $0.592685 * * *$ \\
\hline & & & {$[14.02066]$} & {$[7.225616]$} \\
\hline \multirow[t]{2}{*}{ LFTA(-2) } & & & & $0.205394 * *$ \\
\hline & & & & {$[2.546219]$} \\
\hline R-squared & 0.745545 & 0.771511 & 0.902591 & 0.906156 \\
\hline Ajusted R-squared & 0.743826 & 0.768402 & 0.900576 & 0.903531 \\
\hline \multirow[t]{2}{*}{ LM test } & 115.0502 & 88.05096 & 6.938811 & 3.831031 \\
\hline & {$[0.00000]$} & {$[0.00000]$} & {$[0.0013]$} & {$[0.0240]$} \\
\hline \multirow[t]{2}{*}{ White test } & 2.015451 & 9.488133 & 1.924443 & 1.197382 \\
\hline & {$[0.1369]$} & {$[0.00000]$} & {$[0.0608]$} & {$[0.2878]$} \\
\hline
\end{tabular}

In model 1, there are two variables including only the number of foreign tourists (dependent variable) and the exchange rate (independent variable). The regression results show that the exchange rate had a positive impact on the number of foreign visitors at the $1 \%$ significance level. This implies that the devaluation of the Vietnamese currency has had a positive impact on the foreign tourist arrivals to this country. However, the regression result of model 1 cannot pass the diagnostic tests when the LM test result confirms that the estimated result has a serial correlation problem. In model 2 , the exchange rate variable still has a positive impact on the number of foreign tourists. Besides, the coefficient value of the dummy variable is implied that the international integration process (WTO) has a negative impact on the number of foreign tourists at the $1 \%$ significance level. Similar to the first model, the estimated result of model 2 also does not guarantee reliability when diagnostic tests show both the serial correlation and heteroskedasticity are confirmed in the estimation result.

In the next models, the lag variables of the foreign tourist arrivals will be added in the econometric equation. As seen in the result of model 3, the one lag of the LFTA has a positive impact on the LFTA 
at the $1 \%$ significance level. This evidence suggests that there seems to be a positive spillover effect (as a word-of-mouth effect) of foreign visitors who have been to a tourism destination (see Viglia et al., 2016; Doosti et al., 2016) in the case of Vietnam. However, model 3 could not pass diagnostic tests when the LM testing result has shown the serial correlation phenomenon. The result of model 4 also faces a similar problem when the serial correlation is still an obstacle to the reliability of the regression result. We see that all the lag variables of LFTA have positive effects as well as are statistically significant in the number of foreign tourists. The next problem is the question that "Is whether the regression is better if adding more independent variables in the model?". According to Gujarati (2004) who has a recommendation about adding new variables to an econometric model, the suggestion implies that it is worth adding a new variable to the model when gives an Adjusted R square greater, and conversely (Gujarati, 2004, page 264). Based on the received results, we can conclude that the lag variables of LFTA are good for the estimation because they increase the Adjusted R square values obtained from the estimated models.

Table 3

The estimated results (continued)

\begin{tabular}{|c|c|c|c|c|}
\hline \multicolumn{5}{|c|}{ Dependent Variable: LFTA } \\
\hline \multirow[t]{2}{*}{ Variables } & Model 5 & Model 6 & Model 7 & Model 8 \\
\hline & \multicolumn{4}{|c|}{ Coefficient } \\
\hline \multirow[t]{2}{*}{ Constant } & $-2.238873 * * *$ & $-2.297242 * * *$ & $-2.308898 * * *$ & $-2.119779 * *$ \\
\hline & {$[-2.657045]$} & {$[-2.680422]$} & {$[-2.658766]$} & {$[-2.423315]$} \\
\hline \multirow[t]{2}{*}{ LEXCH } & $0.630568 * * *$ & $0.648403 * * *$ & $0.653006 * * *$ & $0.595365 * *$ \\
\hline & {$[2.757533]$} & {$[2.781309]$} & {$[2.757966]$} & {$[2.489680]$} \\
\hline \multirow[t]{2}{*}{ WTO } & -0.021566 & -0.022911 & -0.025571 & -0.025946 \\
\hline & {$[-1.091746]$} & {$[-1.140369]$} & {$[-1.252924]$} & {$[-1.257469]$} \\
\hline \multirow[t]{2}{*}{$\operatorname{LFTA}(-1)$} & $0.553949 * * *$ & $0.561161 * * *$ & $0.558903 * * *$ & $0.557739 * * *$ \\
\hline & {$[6.712495]$} & {$[6.621052]$} & {$[6.559065]$} & {$[6.544661]$} \\
\hline \multirow[t]{2}{*}{ LFTA(-2) } & 0.087733 & 0.092177 & 0.093634 & 0.096638 \\
\hline & {$[0.930811]$} & {$[0.968734]$} & {$[0.958500]$} & [0.991651] \\
\hline \multirow[t]{2}{*}{ LFTA(-3) } & $0.194677 * *$ & $0.219588^{*}$ & $0.222971 * *$ & $0.191651^{*}$ \\
\hline & {$[2.363017]$} & {$[2.298852$} & {$[2.316760]$} & {$[1.956693]$} \\
\hline \multirow[t]{2}{*}{$\operatorname{LFTA}(-4)$} & & -0.042914 & -0.029100 & -0.038038 \\
\hline & & {$[-0.506429]$} & [0.297445] & {$[-0.388484]$} \\
\hline \multirow[t]{2}{*}{$\operatorname{LFTA}(-5)$} & & & -0.018441 & -0.089020 \\
\hline & & & {$[-0.215900]$} & {$[-0.911547]$} \\
\hline \multirow[t]{2}{*}{ LFTA(-6) } & & & & 0.131145 \\
\hline & & & & [1.533837] \\
\hline R-squared & 0.909037 & 0.908298 & 0.907473 & 0.907803 \\
\hline Ajusted R-squared & 0.905811 & 0.904339 & 0.902746 & 0.902340 \\
\hline \multirow[t]{2}{*}{ LM test } & 0.009214 & 1.336623 & 0.568411 & 2.953374 \\
\hline & {$[0.9908]$} & {$[0.2661]$} & {$[0.5678]$} & {$[0.0556]$} \\
\hline \multirow[t]{2}{*}{ White test } & 1.002348 & 0.950849 & 0.708130 & 0.700204 \\
\hline & {$[0.4630]$} & {$[0.5388]$} & {$[0.8721]$} & {$[0.9025]$} \\
\hline
\end{tabular}

Subsequent models are estimated to find the optimal one for our data set. As we mentioned in the methodology, lag variables of the LFTA are continuously added to the econometric equation. In other models, the regression results pass the diagnostic test and free with the serial correlation and heteroskedasticity phenomenon. The estimation results are also quite uniform with previous results which indicate the exchange rate has a positive impact on the number of foreign tourists. However, the impact of WTO variable (as a proxy of the economic integration) on the foreign tourist arrivals is still not enough statistically significant. The value of Adjusted R-square is maximized at the three lags of foreign tourist arrivals and then gradually decreased at the adding lags of the model. This indicator indicates that the lag length should stop at the three lags of the foreign tourist arrivals as well as we should not continue to add more lag variables into the regression model. 
So the regression result according to model 5 is selected as the optimal econometrics equation. Based on the estimation result of the model 5 , if the exchange rate increases by $1 \%$, the number of foreign tourist arrival to Vietnam will increase by $0.63 \%$ at the $1 \%$ significance level as well. So we can conclude that the exchange rate has a positive effect on the demand for foreign tourists in Vietnam. Although this finding is not consistent with the previous results in some emerging tourism market, e.g. Thailand (McDowall \& Wang, 2009) or Pakistan (Meo et al., 2018), however, at least our investigated result is also supported by some results in the developed countries (Balaguer \& Cantavella-Jordá, 2002; Quadri $\&$ Zheng, 2010). About the lag variables, if the number of foreign tourist arrival rises by $1 \%$ in the first lag period, it will result in increasing the number of foreign tourists in the current period by $0.55 \%$ at the $1 \%$ significance level. The similar result at the third lag variable, if the number of foreign tourist arrival is increased by $1 \%$ in the third lag of period will result in increasing the foreign tourists in the current period by $0.19 \%$ at the $1 \%$ significance level. We have found a positive effect of word of mouth in the case of Vietnam through travelers. However, the positive word-of-mouth effect is decreasing time by time and the evidence in Vietnam is quite consistent with the tourism trend in many countries. Finally, the R-square value (as 0.9090) shows that the estimated function has explained $90.90 \%$ of the variability of the foreign tourist arrivals coming to Vietnam in the study period. The estimated function could be presented by the below form.

$$
\begin{gathered}
\text { LFTA }_{t}=-2.23+0.63 \mathrm{LEXCH}_{\mathrm{t}}-0.02 \mathrm{WTO}_{\mathrm{t}}+0.55 \mathrm{LFTA}_{\mathrm{t}-1}+0.08 \mathrm{LFTA}_{\mathrm{t}-2}+0.19 \mathrm{LFTA}_{\mathrm{t}-3} \\
\text { R square }=0.9090 \quad \text { Ajusted R square }=0.9058
\end{gathered}
$$

To further illustrate the quantitative impact of the exchange rate on the foreign tourist arrival to Vietnam, our statistics are represented by a scatter chart with a vertical axis representing the exchange rate $(\mathrm{LEXCH})$ and the horizontal axis of representation the foreign tourist arrival (LFTA). Besides, a regression line is also drawn to show more clearly about the relationship between the two variables. The graph and regression line clearly illustrate the positive relationship between the exchange rate and the number of foreign tourist arrival coming to Vietnam during the study period (see Fig. 4). This chart continues to show the compatibility between the quantitative regression and the real statistics in Vietnam, this evidence helps to further reinforce the reliability of the regression results in the previous part.

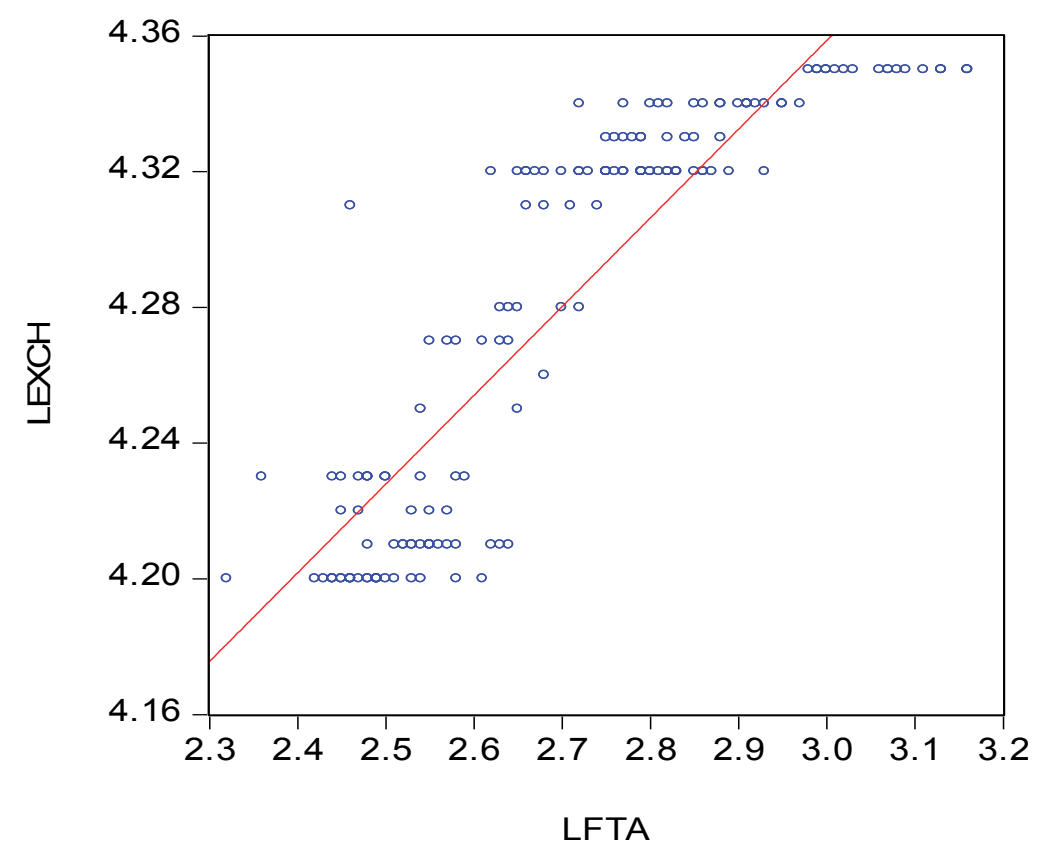

Fig. 4. Exchange rate and foreign tourist arrivals to Vietnam

The regression results have provided implications for the Vietnamese policymakers that the increase in the exchange rate by the government is a good effect to assist the demand for foreign visitors to Vietnam. 
However, if the policymakers are too abusive to use this tool, the negative effect can occur when the domestic currency is strongly devalued causing negative effects on the economy (inflation coming from the increased price of import). Inflation would deteriorate the destination image in the opinion of foreign tourists (McDowall \& Wang, 2009). In this part, we will use the Granger causality test (Granger, 1988) to further analyze the relationship between the exchange rate and the number of foreign tourists coming to Vietnam during the study period. Following the estimated results of the quantitative analysis by the OLS regression method in the above section, we will continuously choose the three lags of the variables as the optimal lag length for the Granger causality test. The causal testing result is shown in the table below.

\section{Table 4}

Results of the Granger causality test

\begin{tabular}{lccc}
\hline The null hypothesis $\left(\mathrm{H}_{0}\right)$ & Number of observations & F-Statistic & P-value \\
\hline LEXCH does not Granger Cause LFTA & 147 & 2.76446 & 0.0443 \\
LFTA does not Granger cause LEXCH & & 1.58500 & 0.1957 \\
\hline
\end{tabular}

Source: Author calculates from the research data

The Granger test result shows that there exists a one-way causality effect from the exchange rate to the foreign tourist arrival without the opposite direction. Specifically, the null hypothesis of "the exchange rate does not Granger cause the number of foreign tourist arrival coming to Vietnam" has been rejected at the 5\% significance level (P-value is 0.0443 ). In the contrast side, we cannot reject the null hypothesis of "the number of foreign visitors does not Granger cause the exchange rate" (P-value is 0.1957). The causality testing result has supplemented and clarified the regression results in the previous section and thereby helped the policymakers get the better information about the real impact of exchange rate policy on the demand of foreign tourist arrival to Vietnam over the past time.

The result of the Granger causality test could be interpreted as a fluctuation in the exchange rate which leads to a change in the number of foreign tourists, however, the change in the number of foreign tourists could not lead to a fluctuation in the exchange rate in Vietnam during the study period. So the Granger testing result is combined with the regression results (see Table 1 and 2) help us deeply understand more about the relationship between the exchange rate and the demand for foreign visitors to Vietnam. There is no causal relationship from the number of foreign tourists to the exchange rate that is also consistent with the actual development of Vietnam's tourism over time. As we know, the expenditure of foreign tourists will increase the supply of foreign currencies (usually USD), if the among of foreign currency is large enough, it will have the opposite effect and cause fluctuating in the exchange rate. However, according to the data from the tourism authority in Vietnam, foreign tourists have spent less and their trips were quite short. In more details, according to the statistics of the Vietnam National Administration of Tourism, foreign visitors spend of an average of $\$ 900$ on a trip to Vietnam, compared with $\$ 1,105, \$ 1,109$ and $\$ 1,565$ spent in Singapore, Indonesia, and Thailand respectively. Therefore, their expenditures in Vietnam do not seem to be enough to fluctuate the exchange rate. Our findings also imply that the policymakers and tourism businesses in Vietnam need additional solutions to boost visitor spending as well as extend their trips. This is also a strong supporting for the aggregate demand (through a multiplier effect) in boosting economic growth.

\section{Conclusion and policy implication}

As one of the emerging tourism markets with a fast growth rate of foreign tourists over the previous years, Vietnam's tourism industry has become a "rising star" among the economic sectors that promoted the Vietnamese economic growth. Therefore, our investigated result also provides good evidence for the Vietnamese policymakers in order to develop the tourism sector in the future. Because the fluctuation of the exchange rate has been an anxious issue for the policymakers in other emerging tourism markets, so the development experience of Vietnam's tourism also is a useful reference for these countries.

Our article maybe is the first quantitative studies on the impact of the exchange rate on foreign tourist arrival in Vietnam. Our data is a monthly form collected in the period 2006-2018. The regression results have shown that the exchange rate had a positive impact on the number of foreign tourists. Besides, the 
foreign tourist arrival has also been positively affected by the number of foreign tourists coming in the previous period. However, the impact of international integration has not statistically been significant enough to make conclusions about the effect of this variable. Finally, the result of the Granger causality test shows that there is only a one-way causal relationship from the exchange rate to the number of foreign tourists without the opposite as well.

Based on the quantitative results, as a reassure about exchange rate fluctuations, some implications can be drawn for the policymakers in the emerging tourism markets. Firstly, the policymakers should note that if the exchange rate increases, it will have a positive impact on the number of foreign tourists coming to Vietnam, however, it should be considered that if the exchange rate raises too fast, it will lead to macro instability and will indirectly harm tourism activities. Secondly, foreign tourists in the previous period had a positive impact on the current number of tourists during the study period, this situation shows a positive spread of tourists through the word-of-mouth advertisement. Thus, the policymakers need to have solutions to increase visitors' satisfaction in order to create good memories when staying and visiting in Vietnam. And from there they will help promote the Vietnamese destinations when meeting other people wishing to travel. Thirdly, the government of Vietnam should promote the attraction of investment in the tourism sector to improve the quality of infrastructure, improve the quality of service for tourists and create a series of leisure activities to pull longer staying time of visitors as well as increase their spending on domestic goods and services (this can be considered as on-site export activity). The development of tourism and the growth of foreign tourists in the coming time will be an important driving force to boost Vietnam's economic growth. The exchange rate lesson from Vietnam is also the value experiences of countries on the path of developing tourism to a leading service sector in promoting economic growth.

\section{References}

Balaguer, J., \& Cantavella-Jorda, M. (2002). Tourism as a long-run economic growth factor: the Spanish case. Applied economics, 34(7), 877-884.

Clark, H., \& and Miller, K. (2017). Vietnamese food: 40 delicious dishes you'll love, CNN travel, sourced at https://edition.cnn.com/travel/article/vietnam-food-dishes/index.html

Doosti, S., Jalilvand, M. R., Asadi, A., Khazaei Pool, J., \& Mehrani Adl, P. (2016). Analyzing the influence of electronic word of mouth on visit intention: the mediating role of tourists' attitude and city image. International Journal of Tourism Cities, 2(2), 137-148.

Granger, C. W. (1988). Some recent development in a concept of causality. Journal of econometrics, 39(1-2), 199-211.

Gujarati, D. N. (2004). Basic econometrics, $4^{\text {th }}$ ed., Mc Graw-Hill, USA.

Lim, C., \& Zhu, L. (2017). Dynamic heterogeneous panel data analysis of tourism demand for Singapore. Journal of Travel \& Tourism Marketing, 34(9), 1224-1234.

McDowall, S., \& Wang, Y. (2009). An analysis of international tourism development in Thailand: 19942007. Asia Pacific Journal of Tourism Research, 14(4), 351-370.

Meo, M. S., Chowdhury, M. A. F., Shaikh, G. M., Ali, M., \& Masood Sheikh, S. (2018). Asymmetric impact of oil prices, exchange rate, and inflation on tourism demand in Pakistan: new evidence from nonlinear ARDL. Asia Pacific Journal of Tourism Research, 23(4), 408-422.

Quadri, D. L., \& Zheng, T. (2010). A revisit to the impact of exchange rates on tourism demand: The case of Italy. The Journal of Hospitality Financial Management, 18(2), 47-60.

Surugiu, C., Leitão, N. C., \& Surugiu, M. R. (2011). A panel data modelling of international tourism demand: Evidences for Romania. Economic research-Ekonomska istraživanja, 24(1), 134-145.

Tang, J., Sriboonchitta, S., Ramos, V., \& Wong, W. K. (2016). Modelling dependence between tourism demand and exchange rate using the copula-based GARCH model. Current Issues in Tourism, 19(9), 876-894.

Yazdi, S. K., \& Khanalizadeh, B. (2017). Tourism demand: a panel data approach. Current Issues in Tourism, 20(8), 787-800. 
Vietnam National Administration of Tourism (2018). Tourism statistics. Available at http://www.vietnamtourism.gov.vn/

Vita, G. D., \& Kyaw, K. S. (2013). Role of the exchange rate in tourism demand. Annals of Tourism Research, 43, 624-627.

Viglia, G., Minazzi, R., \& Buhalis, D. (2016). The influence of e-word-of-mouth on hotel occupancy rate. International Journal of Contemporary Hospitality Management, 28(9), 2035-2051.

World Tourist Organization (2017). Tourism Highlights - 2017 Editions. Madrid, Spain.

Webber, A. G. (2001). Exchange rate volatility and cointegration in tourism demand. Journal of Travel research, 39(4), 398-405.

World Bank (2018). Overview. [Online access September 12, 2018] http://www.worldbank.org/en/country/vietnam/overview

World Economic Forum (2007). The Travel \& Tourism Competitiveness Report 2007. Geneva, Switzerland.

World Economic Forum (2009). The Travel \& Tourism Competitiveness Report 2009. Geneva, Switzerland.

World Economic Forum (2011). The Travel \& Tourism Competitiveness Report 2011. Geneva,Switzerland.

World Economic Forum (2013). The Travel \& Tourism Competitiveness Report 2013. Geneva,Switzerland.

World Economic Forum (2015). The Travel \& Tourism Competitiveness Report 2015. Geneva,Switzerland.

World Economic Forum (2017). The Travel \& Tourism Competitiveness Report 2017. Geneva,Switzerland.

World Tourist Organization (2018). 2017 Annual Report. Madrid, Spain.

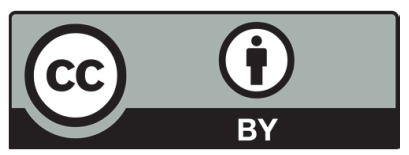

(C) 2019 by the authors; licensee Growing Science, Canada. This is an open access article distributed under the terms and conditions of the Creative Commons Attribution (CCBY) license (http://creativecommons.org/licenses/by/4.0/). 